\section{Investigating the Psychological Resilience of Fathers with Mentally Handicapped Children}

\author{
Erkan Efilti*
}

\author{
Received: 14 November 2018 \\ Revised: $\quad 22$ February 2019 \\ Accepted: 27 February 2019 \\ ISSN: 1307-9298 \\ Copyright (C) IEJEE \\ www.iejee.com
}

\begin{abstract}
The purpose of this study was to examine the psychological resilience of fathers with mentally handicapped children. The study utilized the relational survey model, which is one of the quantitative research models. The unit of analysis of the study was the fathers of children with special educational needs. "The Resilience Scale for Adults" was implemented to construct survey questionnaire and measure the psychological resilience of fathers, as the data collection tool. The study findings depict that the fathers with mentally handicapped children have the highest social competence among the 26-35 age group. The results provide that the group with the highest level of psychological resilience is the group having college or vocational school graduation grade in terms of the educational status of the participants. As for the variable of the job status of fathers, the findings postulate that the future perception level of the employed group is higher than the non-employed group. As a result of the analysis, no statistically significant relationship was found between the psychological resilience levels of total and other sub-dimensions and the total number of children in the family.
\end{abstract}

Keywords: Mentally Handicapped Children, Fatherhood, Psychological Resilience

\section{Introduction}

Psychological resilience is a concept of the process of adaptation to important stress sources such as trauma, familial and relational problems, significant health problems, and financial problems (Tusaie \& Dyer, 2004).

It is not possible to explain psychological resilience in a single dimension. Psychological resilience is a dynamic process and it can be improved. It must be exposed to harsh living conditions and includes effective coping strategies, adaptation, and competence processes. Correspondingly, the individual should be exposed to risk or difficulty, able to leave the situation by adapting to it, and should show a number of personality characteristics that are protective factors of psychological resilience in order to develop the psychological resilience (Gizir, 2007; Gürgan, 2006).

Vulnerability or weakness is completely related to the ability to resist the negative effects of distressing experiences. Hence, weakness or vulnerability is inversely correlated to the psychological resilience. Vulnerability or weakness should be evaluated with emotional, cognitive, and social areas (Truffino, 2010). The mental toughness is another concept that is associated with the concept of the psychological resilience. Four dimensions of mental toughness determined by Jones et al. (2007) are as follows: attitude/mindset (beliefs and adaptation), training, competition management pressure, belief, emotional regulation, awareness, control of emotions and thoughts, managing the situation, and post-competition (managing success and failure) (as cited in Truffino, 2010). It is vital to be exposed to risk and difficulty in life to develop the psychological resilience. Protective factors must be found to reduce and eliminate the negative effects of the risky living conditions. In other words, it must be risky to talk about the psychological resilience (Yılmaz, 2009). Protective factors are an important mechanism for the psychological resilience. The protective factors facilitate the constructive ef- fect of an individual against negative life experiences (Karairmak, 2006).

Masten and Powell (2003) classified the protective factors into three categories which are individual factors, family-related protective factors, and non-family-related protective factors. Individual factors are defined as self-efficacy, self-esteem, intellectual capacity, establishing good environmental relations, adaptability, and self-confidence. Family-related protective factors are described as high-income family, exhibiting good parental characteristics of parents, healthy relationship between parents, and strong family bonds. Non-family-related protective factors are defined as establishing a positive and intimate relationship with an adult from outside the family, studying in a high-ranking school, and having an effective and high-level environment.

Studies on psychological resilience explore the relationship between the factors that are important for early childhood development, such as self-protection and safety, effective learning opportunities, family-provided social support, and the development of self-ordering skills (Masten \& Gewietz, 2006).

One of the protective factors of caregiving families is that they have the ability to think positively when faced with a difficult situation. Both protective and risk factors directly affect the psychological resilience of caregiving families (Bekhet, Zauszniewski, \& Nakhla, 2008).

The risk factors for the psychological resilience are as follows: negative life experiences that an individual may encounter, environmental disasters that the individual is exposed to, all events that affect the individual's wellbeing in terms of his/ her psychological conditions (Karaırmak, 2006). The ways individuals perceive events under the pressure of stress and in times of crisis, attitudes towards these events and methods they use to cope with these situations may vary. Psychologi- 
cal resilience is the personality trait, which is a sign for a positive performance, health, and mood of the individual under the pressure of the stress (Maddi et al., 2006). Many studies have found the relationship between the psychological resilience and emotional intelligence. Martins et al. (2010) found a statistically significant relationship between emotional intelligence and psychological health.

Family plays a significant role in the development of the psychological resilience capacity. Black and Lobo (2008) identified important factors that play a role in the development of the psychological resilience: positive point of view, spiritual values, communication and agreement among family members, flexibility, family time, sharing happiness, and rules of existence and routines (as cited in Truffino, 2010).

Parents of children with disabilities have different emotional behaviors in the face of an unexpected new situation and the challenges posed by this new situation. These behaviors may differ depending on the personalities of the parents, the way they perceive the incident and the quality of their relations. When the reactions of the parents to this situation were examined, it was observed that the first reactions showed the stages of shock, denial, and disbelief. These initial reactions were followed by anger, guilt, shame, sadness, depression, low self, and denial of the child, which consist of irregular emotions. The last point that parents can reach is the acceptance stage of their child that involves recognizing the difficulty of the situation. All parents experiencing these stages differ from each other. Some parents never embrace the situation that their child has a special situation, while some experience these traumatic stages all over again in reaching the child's developmental stages (Ataman, 2005).

Parents of children with disabilities have a higher risk for experiencing higher level of stress in comparison with parents of typically developing children (Mujkanovic, Mujkanovic, Pasalic \& Memisevic, 2017). There is a significant difference between the fathers of children with disabilities and fathers of non-disabled children in terms of their life satisfaction level. In other words, the life satisfaction level of fathers having children with disabilities is lower than fathers of non-disabled children (Aysan \& Özben, 2007).

Parents obliged to prepare their children for life tend to participate more in their children's care responsibilities and education. Especially if the child is disabled, the burden of the family increases exponentially. Even though mothers are generally accepted as the key person directly responsible of the child's care, it is hard to disregard the importance of fathers in care and education of the children with disabilities. Preparing a child with a disability for life is a major challenge for parents in terms of social, economic, and psychological situations. Determining the factors that affect 'psychological resilience levels in fathers' coping processes with this difficulty constitutes the problem of this research.

\section{Purpose of the Study}

The purpose of this study is to examine the level of the psychological resilience of the fathers with mentally handicapped children according to the variables of the study. The research questions of the study are as follows:

\section{Research Questions of the Study:}

1. Whether and to what extent is the level of psychological resilience of fathers with mentally handicapped children associated with the age variable?

2. Whether and to what extent is the level of psychological resilience of fathers with mentally handicapped children associated with the educational status?
3. Whether and to what extent is the level of psychological resilience of fathers with mentally handicapped children associated with the employment status of the fathers?

4. Whether and to what extent is the level of psychological resilience of fathers with mentally handicapped children associated with the number of students?

\section{Methodology}

\section{Research Model of the Study}

Relational survey model, one of the quantitative research models, was implemented to construct a survey questionnaire in the study. Relational survey models are defined as research models aiming to determine the existence and/ or degree of coexistence between two or more variables (Karasar, 2011).

\section{Study Group}

The unit of analysis and the population of the study was fathers with mentally handicapped children and benefited from special educational services. The sample consisted of 50 fathers. Table 1 depicts the descriptive frequency and percentage values of the study group.

Table1. The descriptive frequency and percentage values of the study group

\begin{tabular}{|c|c|c|}
\hline Demographic Features & $f$ & $\%$ \\
\hline \multicolumn{3}{|l|}{ Age } \\
\hline $18-25$ & 4 & 8.0 \\
\hline $26-35$ & 15 & 30.0 \\
\hline $36-45$ & 15 & 30.0 \\
\hline 46 and over & 16 & 32.0 \\
\hline \multicolumn{3}{|l|}{ Educational Status } \\
\hline Illiterate & 3 & 6.0 \\
\hline Primary school graduate & 19 & 38.0 \\
\hline Secondary school graduate & 6 & 12.0 \\
\hline High-school graduate & 18 & 36.0 \\
\hline $\begin{array}{c}\text { Bachelor's/Associate's Degree } \\
\text { graduate }\end{array}$ & 4 & 8.0 \\
\hline \multicolumn{3}{|l|}{ Job Status } \\
\hline Employed & 19 & 38.0 \\
\hline Unemployed & 31 & 62.0 \\
\hline Total & 50 & 100 \\
\hline
\end{tabular}

Descriptive analysis was used to see the main features of the dataset. Descriptive statistics of SPSS provided frequency tables and the distribution of the variables. A frequency table of each study variable was provided independently to show how the responses were distributed. Table1 depicts the details.

\section{Data Collection Instruments}

A survey scale consisting 2 parts was used to construct a survey questionnaire. "The Personal Information Form" was a self-structured questionnaire asking participants demographic features such as father's age, educational status, employment status, and total number of children in the family. "The Resilience Scale for Adults" (Friborg et al., 2003) was implemented to collect data on the psychological resilience of the fathers. 


\section{The resilience scale for adults}

The Resilience Scale for Adults developed by Friborg et al. (2003) focusing on protective resources for the protection of psychological resilience consists of 33 items (as cited in Basım \& Çetin, 2011).

In the scale, the response set was designed in accordance with the five-point Likert Scale, in which the positive and negative characteristics were on different sides in order to keep away from the prejudiced assessments (Basım \& Çetin, 2011).

The validity and reliability of the study of the Psychological Resilience Scale for Adults was conducted by Basım and Çetin (2011) and consisted of 33 items and 6 sub-dimensions. The sub-dimensions and items of the scale were determined as follows: structured style $(3,9,15,21)$, planned future $(2,8,14,20)$, family cohesion $(5,11,17,23,26,32)$, self-perception $(1,7,13,19,28,31)$, social competence $(4$ $10,16,22,25,29)$, and social resources $(6,12,18,24,27$, $30,33)$. In the scale, the questions of $1,3,4,8,11,12,13$, $14,15,16,23,24,25,27,31,33$ were reverse-scored items. Basım and Çetin (2011) conducted the validity of factor structure of the scale with a sample group of 350 students. As a result of the analysis, the calculated values of the Root Mean Square Error of Approximation (RMSEA) was .053, Tucker Lewis Index (TLI) was .91, while Comparative Fit Index (CFI) was .92. The CFI and TLI must be bigger than .9 and RMSEA must be smaller than .05 to establish the model as reasonably fit.

The results showed that the six-dimensional factor structure had adequate compliance values.

In order to calculate the internal consistency of the scale, Cronbach's Alpha values of the sub-dimensions and the item total correlations were calculated for two different sample groups. Item total correlation coefficients ranged from .20 to .52 for the two sample groups. Total Cronbach's Alpha coefficients were calculated as .86 for each sample (Basım \& Çetin, 2011). A Cronbach's Alpha score greater than .70 provides a satisfactory internal consistency for the study.

The test-retest method was carried out with a total of 350 participants. As a result of the analysis, the Pearson correlation coefficients of the sub-dimensions between the two test applications were as follows: $.72(p<.01)$ for the self-perception, $.75(p<.01)$ for the planned future, .68 ( $p<$ $.01)$ for the structured style, $.78(p<.01)$ for the social competence, .81 $(p<.01)$ for the family cohesion and $.77(p<$ .01) for the social resources (Basım \& Çetin, 2011)

\section{Findings}

This section presents the data analyses and findings of the study with a set of recommendations.

Findings on the Differentiation of the Psychological Resilience of the Fathers with Mentally Disabled Children by Their Ages

Kruskal Wallis-H Test was implemented to determine whether the total mean ranks of the Resilience Scale for Adults and mean ranks of its sub-dimensions differ from each other in terms of the age of the fathers. Table 2 provides the results.

As Table 2 depicts, the difference between the mean ranks of fathers having children with special educational needs and the mean ranks of groups were not statistically significant in terms of the age variable, except for social competence sub-dimension. As the findings indicate, the social competence sub-test mean ranks of the groups are statistically significant at the .05 level $(\chi 2=9.656 ; s d=3$; $p<.05$ ) by the age variable. As for the mean ranks of the groups, the 26-35 age group has the highest level of social competence, and it is followed by the 36-45, 18-25, 45 and over age groups, respectively. Effect size calculations have become important criteria for reporting of research, supporting null hypothesis significance testing and obtaining higher quality statistical results (Özsoy \& Özsoy, 2013). According to the eta square values $\left(\eta^{2}\right)$ calculated to test the size of the age groups independent on the Psychological Resilience scores, it is seen that the participants' age groups has a medium effect $\left(\eta^{2}=0.05\right)$ on total psychological resilience scores.

Findings on the Differentiation of the Psychological Resilience of the Fathers with Mentally Disabled Children by Their Educational Status

Kruskal Wallis-H Test was implemented to determine whether the total mean ranks of the Resilience Scale for Adults and mean ranks of its sub-dimensions differ from each other by the educational status of the fathers. Table 3 provides the results.

Table 3 gives the mean ranks of the groups. The self-perception sub-test mean ranks of the groups are statistically significant at the .05 level $(x 2=10.603 ; s d=4 ; p<.05)$ by educational status of the fathers. The findings of the analysis provide us that the Bachelor's or Associate's degree graduate group has the highest self-perception level, and it is respectively followed by primary school, high-school, secondary school graduate, and illiterate groups. The social competence sub-test mean ranks of the groups are statistically significant at the .01 level $(x 2=14.317$; $s d=4$; $p<.01$ ). The mean ranks of the groups findings provide us that the Bachelor's or Associate's degree graduate group has the highest social competence level, and it is respectively followed by secondary school, high-school, primary school graduate and illiterate groups. The total psychological resilience mean ranks of the groups are statistically significant at the .05 level $(\chi 2=10.271 ; s d=4 ; p<.05)$. The mean ranks of the groups findings reveal that the Bachelor's or Associate's degree group has the highest psychological resilience level, and it is respectively followed by primary school, secondary school, high-school graduate, and illiterate groups. According to the findings, the difference between the other sub-test mean ranks of the groups was not statistically significant by the educational status of the participants $(p>.05)$. According to the eta square values $\left(\eta^{2}\right)$ calculated to test the size of the educational status groups independent on the Psychological Resilience scores, it is seen that the participants' educational status groups has a large effect $\left(\eta^{2}=0.13\right)$ on total psychological resilience scores.

Findings on the Differentiation of the Psychological Resilience of the Fathers with Mentally Disabled Children by Their Job Status

Mann Whitney-U Test was implemented to determine whether the total mean rank of the Resilience Scale for Adults and mean ranks of its sub-dimensions differ from each other by the employment status of the fathers. Table 4 gives the details.

Table 4 depicts that planned future sub-test mean ranks of the groups differed statistically at the .05 level $(U=178.000$, $p<.05)$ by the job status of the fathers. The mean ranks of the groups results provide us that the planned future level of employed group is higher than the unemployed group. The results reveal that self-perception sub-test mean ranks of the groups differed statistically at the .05 level $(\mathrm{U}=$ $184.500, p<.05)$. The mean ranks of the groups provide that the self-perception level of employed group is higher 
Table 2. Findings on the Differentiation of the Psychological Persistence of Fathers with Mentally Disabled Children by Their Ages

\begin{tabular}{|c|c|c|c|c|c|c|c|}
\hline & Groups & $n$ & Mean Rank & $x^{2}$ & $s d$ & $\eta^{2}$ & $p$ \\
\hline \multirow{5}{*}{ Structured Style } & $18-25$ age & 4 & 23.75 & \multirow{5}{*}{5.905} & \multirow{5}{*}{3} & \multirow{5}{*}{0.06} & \multirow{5}{*}{.116} \\
\hline & 26-35 age & 15 & 29.40 & & & & \\
\hline & $36-45$ age & 15 & 29.47 & & & & \\
\hline & 45 and over age & 16 & 18.56 & & & & \\
\hline & Total & 50 & & & & & \\
\hline \multirow{5}{*}{ Planned Future } & $18-25$ age & 4 & 18.38 & \multirow{5}{*}{3.090} & \multirow{5}{*}{3} & \multirow{5}{*}{0.00} & \multirow{5}{*}{.378} \\
\hline & $26-35$ age & 15 & 29.87 & & & & \\
\hline & $36-45$ age & 15 & 26.30 & & & & \\
\hline & 45 and over age & 16 & 22.44 & & & & \\
\hline & Total & 50 & & & & & \\
\hline \multirow{5}{*}{ Family Coherence } & $18-25$ age & 4 & 27.75 & \multirow{5}{*}{2.043} & \multirow{5}{*}{3} & \multirow{5}{*}{0.02} & \multirow{5}{*}{.563} \\
\hline & 26-35 age & 15 & 27.67 & & & & \\
\hline & 36-45 age & 15 & 27.30 & & & & \\
\hline & 45 and over age & 16 & 21.22 & & & & \\
\hline & Total & 50 & & & & & \\
\hline \multirow{5}{*}{ Self-Perception } & $18-25$ age & 4 & 16.38 & \multirow{5}{*}{6.201} & \multirow{5}{*}{3} & \multirow{5}{*}{0.07} & \multirow{5}{*}{.102} \\
\hline & $26-35$ age & 15 & 32.60 & & & & \\
\hline & $36-45$ age & 15 & 24.73 & & & & \\
\hline & 45 and over age & 16 & 21.84 & & & & \\
\hline & Total & 50 & & & & & \\
\hline \multirow{5}{*}{ Social Competence } & $18-25$ age & 4 & 22.25 & \multirow{5}{*}{9.656} & \multirow{5}{*}{3} & \multirow{5}{*}{0.14} & \multirow{5}{*}{$.022 *$} \\
\hline & $26-35$ age & 15 & 34.73 & & & & \\
\hline & $36-45$ age & 15 & 24.13 & & & & \\
\hline & 45 and over age & 16 & 18.94 & & & & \\
\hline & Total & 50 & & & & & \\
\hline \multirow{5}{*}{ Social Resources } & 18-25 age & 4 & 19.00 & \multirow{5}{*}{1.688} & & & \\
\hline & $26-35$ age & 15 & 25.07 & & & & \\
\hline & $36-45$ age & 15 & 28.83 & & 3 & 0.02 & .640 \\
\hline & 45 and over age & 16 & 24.41 & & & & \\
\hline & Total & 50 & & & & & \\
\hline & $18-25$ age & 4 & 21.63 & & & & \\
\hline & $26-35$ age & 15 & 31.43 & & & & \\
\hline $\begin{array}{l}\text { Psychological } \\
\text { Resilience Total }\end{array}$ & $36-45$ age & 15 & 26.97 & 5.606 & 3 & 0.05 & .132 \\
\hline & 45 and over age & 16 & 19.53 & & & & \\
\hline & Total & 50 & & & & & \\
\hline
\end{tabular}

${ }^{*} p<.05 ;{ }^{*} p<.01$

than the unemployed group. According to the results of the analysis, the difference between the total and other sub-test mean ranks of the groups was not statistically significant by the employment status of the participants ( $p>.05)$. According to the eta square values $\left(\eta^{2}\right)$ calculated to test the size of the job status (employed/unemployed) independent on the Psychological Resilience scores, it is seen that the participants' working status has a small effect $\left(\eta^{2}=0.01\right)$ on total psychological resilience scores.

Findings on the Relationship between the Psychological Resilience of the Fathers with Mentally Disabled Children and the Total Number of Children in Family

The purpose of this study is to examine the relationship between the psychological resilience of fathers with mentally handicapped children and the total number of children in the family. For this purpose, Pearson Moments Multiplication Correlation Coefficient technique was implemented. Table 5 and Table 6 provide the arithmetic mean of the scores taken from the RSA by the sample group, the standard error of the arithmetic mean, and the standard deviation values.

The statistical analysis was conducted to determine the relationship between the psychological resilience levels of the fathers with mentally handicapped children and the total number of children in the family. As Table 5 and Table 6 reveal, a statistically significant correlation was found only between the self-perception sub-test means and the total number of children in the family with a negative relationship $(r=-.333, p<.01)$. Hence, it is safe to say that the self-perception sub-test means are negatively related to the total number of children in the family.

According to this result, the self-perception level increases while the total number of children in the family decreases. As a result of the analysis, there is no statistically significant relationship between the other sub-dimensions and total psychological resilience level and the total number of children in the family ( $p>$.05). 
Table 3. Findings on the Differentiation of the Psychological Persistence of the Fathers with Mentally Disabled Children by Their Educational Status

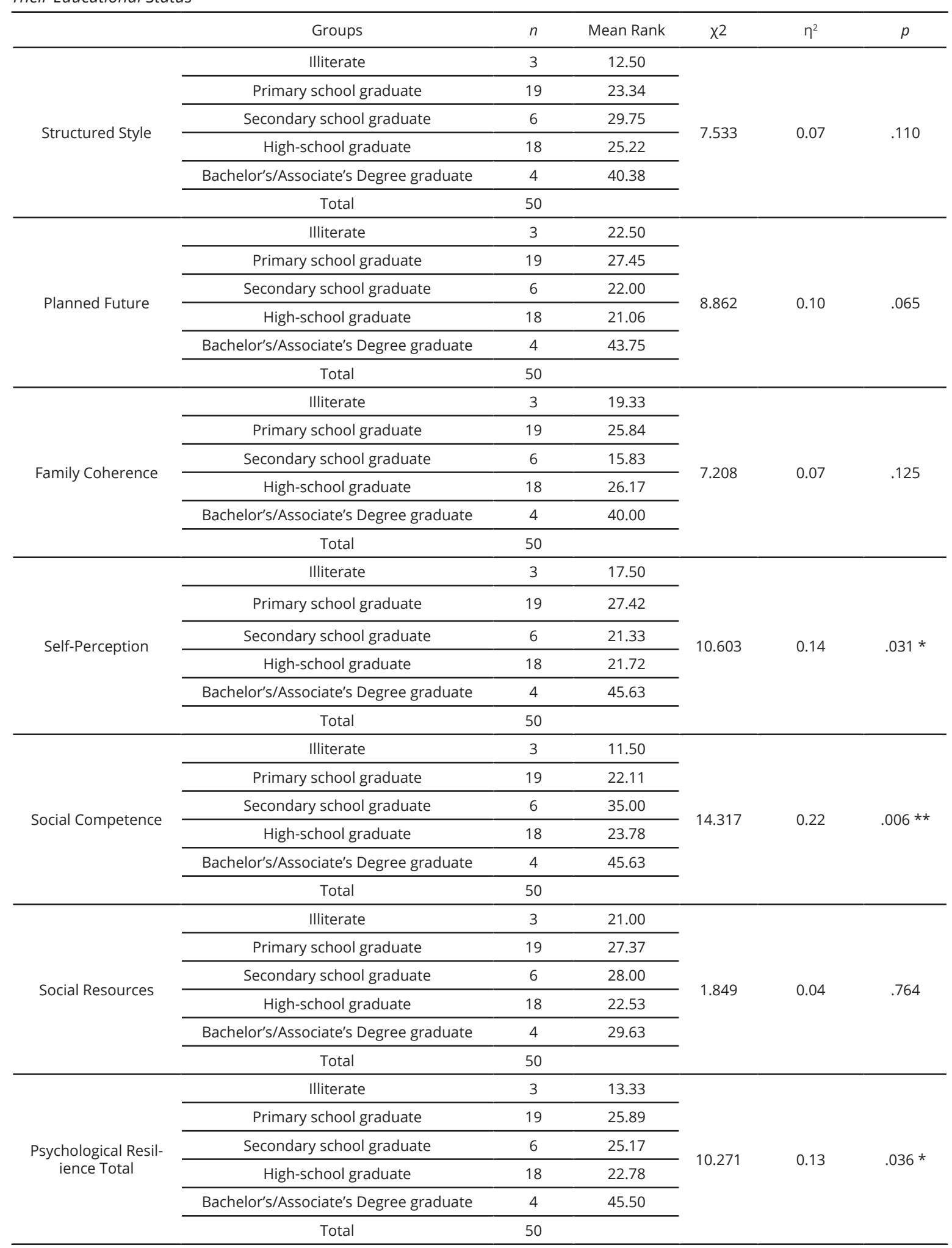

${ }^{*} p<.05 ; * * p<.01$

\section{Results and Discussion}

The purpose of the study was to determine whether the psychological resilience of the fathers with mentally handicapped children by the age, educational status, employment status of the fathers, and the number of children in family.

The psychological resilience is a concept of adaptation to important stress sources such as trauma, familial and re- lational difficulties, significant health problems, and financial problems (Tusaie \& Dyer, 2004).

The unit of analysis of the study was fathers with mentally handicapped children. These fathers are faced with trauma at the first time when they have a child with a disability and live together with children having lifelong difficulties. This situation gives rise to several communication and adjustment problems in the family and it brings a great deal of health problems and additional expenses. Therefore, it 
Table 4. Findings on the Differentiation of the Psychological Persistence of Fathers with Mentally Disabled Children by Their Employment Status

\begin{tabular}{|c|c|c|c|c|c|c|c|c|}
\hline & Job Status & $n$ & $\begin{array}{l}\text { Mean } \\
\text { Rank }\end{array}$ & $\begin{array}{l}\text { Signed } \\
\text { Rank }\end{array}$ & Mann Whitney U & $z$ & $\eta^{2}$ & $p$ \\
\hline \multirow{2}{*}{ Structured Style } & Employed & 19 & 22.71 & 431.50 & \multirow{2}{*}{241.500} & \multirow{2}{*}{-1.063} & \multirow{2}{*}{0.02} & \multirow{2}{*}{.288} \\
\hline & Unemployed & 31 & 27.21 & 843.50 & & & & \\
\hline \multirow{2}{*}{ Planned Future } & Employed & 19 & 19.37 & 368.00 & \multirow{2}{*}{178.000} & \multirow{2}{*}{-2.343} & \multirow{2}{*}{0.10} & \multirow{2}{*}{$.019 *$} \\
\hline & Unemployed & 31 & 29.26 & 907.00 & & & & \\
\hline \multirow{2}{*}{ Family Coherence } & Employed & 19 & 26.53 & 504.00 & \multirow{2}{*}{275.000} & \multirow{2}{*}{-.390} & \multirow{2}{*}{0.00} & \multirow{2}{*}{.696} \\
\hline & Unemployed & 31 & 24.87 & 771.00 & & & & \\
\hline \multirow{2}{*}{ Self-Perception } & Employed & 19 & 19.71 & 374.50 & \multirow{2}{*}{184.500} & \multirow{2}{*}{-2.203} & \multirow{2}{*}{0.09} & \multirow{2}{*}{$.028^{*}$} \\
\hline & Unemployed & 31 & 29.05 & 900.50 & & & & \\
\hline \multirow{2}{*}{ Social Competence } & Employed & 19 & 21.95 & 417.00 & \multirow{2}{*}{227.000} & \multirow{2}{*}{-1.354} & \multirow{2}{*}{0.03} & \multirow{2}{*}{.176} \\
\hline & Unemployed & 31 & 27.68 & 858.00 & & & & \\
\hline \multirow{2}{*}{ Social Resources } & Employed & 19 & 28.87 & 548.50 & \multirow{2}{*}{230.500} & \multirow{2}{*}{-1.281} & \multirow{2}{*}{0.03} & \multirow{2}{*}{.200} \\
\hline & Unemployed & 31 & 23.44 & 726.50 & & & & \\
\hline \multirow{2}{*}{ Psychological Resilience Total } & Employed & 19 & 23.18 & 440.50 & \multirow{2}{*}{250.500} & \multirow{2}{*}{-.880} & \multirow{2}{*}{0.01} & \multirow{2}{*}{.379} \\
\hline & Unemployed & 31 & 26.92 & 834.50 & & & & \\
\hline
\end{tabular}

${ }^{\star} p<.05 ;{ }^{\star *} p<.01$

Table 5. The Arithmetic Mean of the Scores Taken from the RSA by the Sample Group, the Standard Error of the Arithmetic Mean, and the Standard Deviation Values

\begin{tabular}{|c|c|c|c|c|c|c|c|c|}
\hline Job Status & & $n$ & & $M$ & & se & sd & \\
\hline Structured Style & & 50 & & 10.9600 & & .62984 & 4.45366 & \\
\hline Planned Future & & 50 & & 9.4800 & & .58431 & 4.13171 & \\
\hline Family Coherence & & 50 & & 20.3800 & & .84026 & 5.94152 & \\
\hline Self-Perception & & 50 & & 17.7000 & & .81629 & 5.77203 & \\
\hline Social Competence & & 50 & & 20.1400 & & .89077 & 6.29872 & \\
\hline Social Resources & & 50 & & 23.2000 & & .92978 & 6.57453 & \\
\hline Psychological Resilience Total & & 50 & & 101.8600 & & 3.52889 & 24.95303 & \\
\hline Variables & 1 & 2 & 3 & 4 & 5 & 6 & 7 & 8 \\
\hline 1.The Number of Children & - & & & & & & & \\
\hline 2.Structured Style & -.185 & - & & & & & & \\
\hline 3.Planned Future & -.161 & $.586 * *$ & - & & & & & \\
\hline 4.Family Coherence & .065 & .217 & $.401 * \star$ & - & & & & \\
\hline 5.Self-Perception & $-.333^{* *}$ & $.462 * \star$ & $.726 \star \star$ & $.387 * \star$ & - & & & \\
\hline 6.Social Competence & -.157 & $.567 * \star$ & $.523 * \star$ & $.484 * \star$ & $.632 * \star$ & - & & \\
\hline 7.Social Resources & .171 & .261 & $.414 * \star$ & $.569 * \star$ & $.399 * \star$ & $.518^{* \star}$ & - & \\
\hline 8.Psychological Resilience Total & -.116 & $.646 * \star$ & $.775^{\star \star}$ & $.705^{\star \star}$ & $.791 * \star$ & $.838 * \star$ & $.737 * \star$ & - \\
\hline
\end{tabular}

is safe to say that fathers with mentally handicapped children have the necessary risk factors in order to talk about the concept of psychological resilience. The findings of the study reveal that the fathers with mentally handicapped children have the highest social competence group in the 26-35 age group, followed by $36-45,18-25$ and 45 age groups. The literature shows that the findings of this study are consistent with the findings of the other studies regarding the issue. Bildirici (2014), in his study on the psychological resilience of mothers, found the positive relationship between the age and the psychological resilience, postulating that the psychological resilience increased when the age increased. The difference of the psychological resilience scale scores of the teachers working in the special education schools for handicapped was found to be statistically significant (Uçar, 2014). The findings on the average scores provided us that the mean scores of psychological resilience increased as the age increased. According to the research conducted by Yalçın (2013), the psychological resilience levels of the teachers differed significantly by their ages and the psychological resilience level of the teachers increased as the age of the teachers increased. Some findings in the literature did not support the findings of this study.

The studies of Chan (2003) and Sezgin (2009) found no difference on the psychological resilience levels of the teachers by the age of the participants.

By the educational status of the fathers, the findings of the analysis reveal that the Bachelor's or Associate's degree graduate group has the highest self-perception level and it is respectively followed by primary school, high-school, 
secondary school graduate, and illiterate groups. In the literature, studies supporting the research findings were reached (Akıncı-aydoğan, 1999; Bildirici, 2014; Bozgeyikli \& Şat, 2014; Sucuoğlu, 1995).

In a study, Akıncı-Aydoğan (1999) found an inverse relationship between the educational level of the family and despair. In other words, fathers having higher educational levels can look at the future with more hope and this situation may increase the psychological resilience of the fathers. Bildirici (2014), in her study examining the relationship between mothers' psychological resilience and the family burden, found that the scores on the psychological resilience scale increased as the educational status of the mothers increased. Hence, it is safe to say that the educational status affected psychological resilience. The study of Sucuoğlu (1995) determined that the most important needs of families were to talk to other families of children with disabilities, read books regarding their children, and reach information about teaching skills. For this reason, if fathers' access to information, relevant books and resources, and share information with other families are considered, it is understandable that the educational leve affects psychological resilience.

When the psychological resilience of the fathers with mentally handicapped children was examined by the employment status of the fathers; the difference between the means ranks of the groups was statistically significant for the planned future sub-test according to the employment status of the participants. As for the mean ranks, it is seen that the planned future level of the employed group is higher than the non-employed group. As a result of the analysis, the difference between the mean ranks of the groups was statistically significant for the self-perception sub-test by the employment status of the participants. The findings of the mean ranks give us that the self-perception of the employed group is higher than the non-employed group. The findings of the study by Bildirici (2014) is consistent with the findings of this study, postulating that there was a statistically significant difference between the monthly average income levels and the means of the psychological resilience scale of the mothers having children with special education and participated in the research, and the psychological resilience increased when the family's mean monthly income level increased. With the birth of children with disabilities, there is a significant increase in the family's medical and educational expenses. This can be considered as a situation increasing the future anxiety of the family and significantly decreases the prospects of the future. Smith et al. (2006) reported that there was an increase in the cost of bringing up child as one of the family's potential stress areas. Akıncı Aydoğan (1999) concluded that there was an inverse relationship between family income levels and despair. When fathers are employed, it can reduce this anxiety and lead to the future with more hope, which can be interpreted as a factor that increases the psychological resilience of the fathers.

The findings regarding the relationship between the psychological resilience of fathers with mentally handicapped children and the total number of children in the family indicate that the total number of children in the family decreased as the level of self-perception increased. As a result of the analysis, there is no statistically significant relationship between the other sub-dimensions and total psychological resilience level and the total number of children in the family. A study of Bildirici (2014) found similar results and her findings are consistent with this study. Bildirici (2014) found that there is no statistical difference between the scores obtained from the psychological resilience scale and mothers who have children with special education need to have more than one special education supports the present research findings. Fraternal relationships are defined as the relationship between the birth of the youngest brother and the lifelong (Ahmetoğlu \& Aral, 2008). Since the fraternity is an innate relationship, no other relationship lasts as long as it is (Onat Zoylan, 2005). Siblings, like parents, share sadness, grief, and struggle that may be caused by the insufficiency of the birth of a baby with deficiencies (Seligman \& Darling, 2013). Having normal children in the family provides considerable comfort to the majority of the parents (Gath, 1992). Although it is highlighted in the literature that having siblings has a positive effect on the family, the responsibility of raising a child with a disability is commonly considered as the responsible of the mother, and some of this task and responsibility are shared with the older sisters in the family (Gath, 1992).

Since the unit of analysis and the population of the study were fathers, the presence and number of siblings could explain the effect of the fathers' psychological resilience. On the other hand, Griffiths and Unger (1994) concluded that parents hoped that their children with mental handicapped in the future would be cared for by their normally developing siblings according to the study of 'Views about Planning for the Future among Parents and Siblings of Adults with Mental Retardation'. This expectation in families is also anticipated to affect the psychological resilience of the fathers. This situation is not expected to occur with the findings of this research. It may be thought that there may have been a change in the expectations of families or the researches made in different cultures may have been caused by cultural differences since it has been a long time since the study of Griffiths and Unger (1994) was published. Future researchers can contribute to the literature by examining the similar issues to clarify the situation.

\section{Recommendations}

In the light of findings discussed above, the study has the following suggestions: There are several factors that may affect psychological resilience of the fathers with disabled children. Future research should study the other variables that were not examined by this study.

Governments should increase the facilities providing services for families with children who are in need of special education. The psychological resilience of the fathers varies by their income level and educational status. Adequate social resources and economic support should be provided to these families who have social, emotional, economic, and time difficulties. As the findings of this study have proved that the educational levels of participants positively affect their psychological resilience, ill-informed fathers should be well informed about their children's education and proper behaviors. In addition, some centres should be established to provide psychological support for groups and individuals.

\section{References}

Akıncı-Aydoğan, A. (1999). Özürlü çocuğa sahip anne babaların umutsuzluk düzeylerinin belirlenmesi. Doctoral Dissertation. Hacettepe University, Ankara, Turkey.

Ahmetoğlu, E. \& Aral, N. (2008). Schaeffer kardeş davranışı değerlendirme ölçeğinin Türkçe uyarlaması. Kastamonu Ĕ̆itim Dergisi, 16(2), 379-88.

Ataman, A. (2005). Özel eğitime muhtaç olmanın nedenleri. Özel eğitime giriş (1.baskı). Ankara: Gündüz Eğitim ve Yayıncılık.

Aysan, F. \& Özben, Ş. (2007). Engelli çocuğu olan anne babaların yaşam kalitelerine ilişkin değişkenlerin incelenmesi. Dokuz Eylül Üniversitesi Buca Eğitim Fakültesi Dergisi, 22, 1-6. 
Basım, N. H. \& Çetin, F. (2011). Yetişkinler için psikolojik dayanıklılık ölçeği'nin güvenirlik ve geçerlilik çalışması. Türk Psikiyatri Dergisi, 22(2), 104-114.

Bekhet, A. K., Zauszniewski, J. A., \& Nakhla, W. E. (2008). Loneliness: a concept analysis. Malden, USA: Blackwell Publishing Inc. In Nursing Forum, 43(4), 207-213.

Bildirici F. (2014). Özel eğitime gereksinimi olan çocuğa sahip ailelerde aile yükü ile psikolojik dayanıklılık arasındaki ilişki. Unpublished master's thesis, Haliç University, İstanbul, Turkey.

Bozgeyikli, H. \& Şat, A. (2014). Öğretmenlerde psikolojik dayanıklııı ve örgütsel vatandaşlık davranışlarının bazı değişkenler açısından incelenmesi: Özel okul örneği. Hak iş Uluslararası Emek ve Toplum Dergisi, 3(5), 172191.

Chan, D. (2003). Hardiness and its role in the stres-burnout relationship among prospective teachers in Hong Kong. Teacher and Teacher Education, 19, 381-395.

Gath, A. (1992). The brothers and sisters of mentally retarded children. Children's Sibling Relationships: Developmental and Clinical Issues. Hillsade, NJ: Lawrence Erlbaum Associates Publishers.

Gizir, C. A. (2007). Psikolojik sağlamlık, risk faktörleri ve koruyucu faktörler üzerine bir derleme çalışması. Türk Psikolojik Danışma ve Rehberlik Dergisi, 3(28), 113-128.

Griffiths, D. L. \& Unger, D. G. (1994). Viewsabout planning for the future among parents and siblings of adults with mental retardation. Family Relation, 43, 221-227.

Gürgan, U. (2006). Yılmazlık ölçeği (YÖ): Ölçek geliştirme, güvenirlik ve geçerlik çalışması. Ankara Üniversitesi Eğgtim Bilimleri Fakültesi Dergisi, 39(2), 45-74.

Karaırmak, Ö. (2006). Psikolojik sağlamlık, risk faktörleri ve koruyucu faktörler. Türk Psikolojik Danışma ve Rehberlik Dergisi, 26(3), 129-142.

Karasar, N. (2011). Bilimsel araştırma yöntemi. (22. Baskı). Ankara: Nobel Yayın Dağıtım.

Maddi, S. R., Harvey, R. H., Khoshaba, D. M., Lu, J. L., Persico, M. \& Brow, M. (2006). The personality construct of hardiness, III: Relationships between repression, innovativeness, authoritarianism, and performance. Journal of Personality, 74(2), 575-598.

Martins, A., Ramalho, N. \& Morin, E. (2010). A Comprehensive meta-analysis of the relationship between emotional Intelligence and health. Personality and Individual Differences, 49(6), 554-564.

Masten A.S. \& Gewirtz A.H. (2006). Resilience in development: The importance of early childhood. In: Tremblay RE, Barr RG, Peters RDeV, eds. Encyclopedia on Early Childhood Development [online]. Montreal, Quebec: Centre of Excellence for Early Childhood Development; 2006:1-6. Available at: http://www. child-encyclopedia.com/documents/Masten-GewirtzANGxp.pdf. 08. December, 2018.

Masten, A. S. \& Powell, J. L. (2003). A resilience framework for research, policiy, and practice. (Ed: S. Luthar). Resilience and vulnerabilities: Adaptation in the context of childhood adversities. New York: Cambridge University Press.

Mujkanovic, E., Mujkanovic, E., Pasalic, A., \& Memisevic, H. (2017). Quality of educational support for children with autism spectrum disorder in Bosnia and Herzegovina-Perception of parents and professionals.
International Electronic Journal of Elementary Education, 9(4), 829-836. Retrieved from https://www.iejee. com/index.php/IEJEE/article/view/287. 15. November, 2018.

Onat Zoylan, E. (2005). Engelli kardeşe sahip olan ve olmayan bireylerin kardeş ilişkilerinin belirlenmesi. Unpublished master's thesis, Abant İzzet Baysal University, Bolu, Turkey.

Özsoy, S., \& Özsoy, G. (2013). Effect Size Reporting in Educational Research. Elementary Education Online, 12(2), 334-346.

Seligman, M. \& Darling, R. B. (2013). Ordinary families, special children: A systems approach to childhood disability. International Journal of Early Childhood, 5(1), 66-69.

Sezgin, F. (2009). Relationships between teacher organizational commitment, psychological hardiness and some demographic variables in Turkish primary schools. Journal of Educational Administration, 47(5), 630-651.

Sezgin, F. (2012). illköğretim okulu öğretmenlerinin psikolojik dayanıklılık düzeylerinin incelenmesi. Kastamonu Ĕgitim Dergisi, 20(2), 489-502.

Smith, T. E. C., Gartin, B. C., Murdick, N. L. \& Hilton, A. (2006). Families and children with special needs. New Jersey: Pearson Education.

Sucuoğlu, B. (1995). Özürlü çocuğu olan anne/babaların gereksinimlerinin belirlenmesi. Çocuk ve Gençlik Ruh Sağ/Iğı Dergisi, 2(1), 10-18.

Truffino, J. C. (2010). Resilience: An approach to the concept. Rev PsiQuiatr Salud Ment, 3(4), 145-151.

Tusaie, K. \& Dyer, J. (2004). Resilience: A historical review of the construct. Holist Nurs Pract, 18, 3-8.

Uçar, T. (2014). Özel eğitim öğretmenlerinin psikolojik dayanıklılık düzeylerinin ve mesleki sosyal destek düzeylerinin bazı değişkenler açısından incelenmesi (istanbul ili avrupa yakası örneği). Unpublished master's thesi, İstanbul Aydın University, İstanbul, Turkey.

Yalçın, S. (2013). Illköğretim okulu öğretmenlerinin mesleki tükenmişlik düzeyleri ile stres, psikolojik dayanıklılık ve akademik iyimserlik arasındaki ilişki. Unpublished master's thesi, Gazi University, Ankara, Turkey.

Yılmaz, S. (2009). Illköğretim birinci kademedeki eğitilebilir zihinsel engelli ögrencilerde fizyoterapi yöntemleri kullanılarak çalışan ince motor fonksiyonların yazma becerilerine etkilerinin incelenmesi. Unpublished master's thesi, Selçuk University, Konya, Turkey. 